\title{
Stock Production Research in Canada: A Historical Perspective
}

\author{
by
}

\author{
C. Glerum ${ }^{1}$
}

\section{Abstract}

The development of stock production research in Canada is described, within the context of the Canadian federated system of government. The first two full-time career researchers in stock production started in the fifties and were employed by provincial governments. At that time, most of the research was on bareroot stock. The development of containerized stock production in Canada is briefly described, as well as the impact container stock has had on the stock production scene. Some of the more prominent findings in stock production research on such topics as storage, fertilization, frost hardiness, photoperidicity and root growth are briefly discussed. Concern over governmental funding is also expressed.

\section{Résumé}

Le développement de la recherche sur la production de semis au Canada est élaboré, selon le contexte du système de gouvernement fédéral du Canada. Les deux premiers chercheurs scientifiques à temps plein dans la production de semis ont débuté leurs travaux dans les années cinquante et étaient à l'emploi de gouvernements provinciaux. A cette époque, la majeure partie de la recherche touchait la production en racine nue. Le développement de la production en récipient est brièvement décrit, ainsi que l'impact qu'a eu la production en récipient sur la scène de la production de semis. Quelques-unes des plus importantes découvertes de la recherche sur la production de semis dans des domaines comme l'entreposage, la fertilisation, la résistance au gel, le photopériodisme et la croissance des racines sont brièvement discutées. L'inquiétude entourant le financement par les gouvernements est aussi abordée.

\section{Introduction}

Canada is a federal country consisting of ten provinces and two territories. Within the Canadian federal system the primary responsibility for resource administration, including forestry, is in the hands of provincial governments. The federal government provides only certain services and financial assistance for specific purposes.

The federal government has research programs, which are carried out through a network of six regional forestry centres and two institutes across Canada from St. John's, Newfoundland to Victoria, British Columbia. These research programs are conducted by Forestry Canada, until recently known as the Canadian Forestry Service, to assist the provinces with their forestry programs. For example, the federal government's pest management services (i.e., pathology and entomology), are especially important to the provinces' forestry programs.

Although the federal government's forestry research contributions are still important, there have been major reductions in the funding of research programs since 1969

\footnotetext{
TPrincipal Scientist, Ontario Forest Research Institute, P.O. Box 7400, Maple, Ontario
} L6A 1 S9
(Reed et al. 1978). This trend in reduced funding still prevails today, and is reflected by the continuing reductions in staff, from a 1968 high of about 2200 to about 1200 in 1989. These cutbacks in forestry by the federal government led Sisam (1982) to observe that the federal government has suffered from a chronic uncertainty as to the place of forestry on the national scene. He noted that this is well illustrated by the innumerable commissions, committees, consultants and conferences that have been appointed and/or convened over the years to resolve this uncertainty.

Since forestry is within the jurisdiction of the provinces, it is not surprising that virtually all planting stock is produced by the provinces and/or for the provinces.

Canada's first forest tree nursery was established by the Government of Ontario in 1904 at the Ontario Agricultural College in Guelph. However, this nursery was transferred to Canada's first provincial forestry station at St. Williams, Ontario in 1908 (Zavitz 1947). The first provincial forest tree planting occurred in 1908. It was not until 1922 that two more tree nurseries were established by the Ontario government. The forester E. J. Zavitz was primarily instrumental in initiating the establishment of the tree nurseries system in Ontario. The Quebec government established its first permanent tree nursery in 1908 at Berthierville and the province's first 
planting of forest trees occurred in 1912. The firs i company nursery was started by the Laurentide Company of Grand'Mere, Quebec around 1910 (Leavitt 1913). The British Columbia government established its first permanent tree nursery, Green Timbers, in 1929 at Surrey, B. C. The need for artificial regeneration was not strongly felt in the Maritimes because of the excellent natural regeneration (Leavitt 1913). Nevertheless, the first tree nursery in the Maritimes was established privately in 1927 at Lawrencetown, Nova Scotia and was taken over by that province in 1952. All these nurseries produced bareroot stock; the production of containerized stock did not start until the mid-sixties.

At present there are some 43 tree nurseries and 101 container seedling production centres spread throughout Canada (Table 1) producing some 900 million tree seedlings annually (Table 2). Most of the bareroot nurseries are owned by the provincial governments, while most of the container seedling nurseries are privately owned. Most of the planting stock produced are coniferous species.

\section{The Development of Stock Production Research}

In Canada, research in stock production began soon after the first nurseries were established. However, this type of research really came into its own after World War II, when there was a major increase in stock production. Another significant increase in stock production began in the late 1970's. Between then and now stock production has increased by more than $300 \%$. Increases of such magnitude within a relatively short period of time generate problems. Sound research can help minimize many of these problems.

Since the forests are within the jurisdiction of the provinces, several provinces started their own research establishments. British Columbia created its research organization in 1927. Ontario also initiated a research program in 1927, but it was short-lived for it succumbed to the Great Depression in 1936. Ontario's present research organization (i.e., Ontario Forest Research Institute) was created in 1941 but did not become functional until 1945. Now nearly all provinces have some kind of research organization. The federal government became involved in forest research around 1917, and after World War II it established forestry research centres across Canada. Since the early 1950's, stock production research was mainly carried out by the

Table 1. Number of planting stock production centres in Canada by province in 1984

\begin{tabular}{|c|c|c|}
\hline \multirow[b]{2}{*}{ Province } & \multicolumn{2}{|c|}{$\begin{array}{c}\text { Number of } \\
\text { Planting Stock Production } \\
\text { Centres }\end{array}$} \\
\hline & Bareroot & Container \\
\hline $\begin{array}{l}\text { British Columbia } \\
\text { Alberta } \\
\text { Saskatchewan } \\
\text { Manitoba } \\
\text { Ontario } \\
\text { Quebec } \\
\text { New Brunswick } \\
\text { Nova Scotia } \\
\text { Prince Edward Island } \\
\text { Newfoundland }\end{array}$ & $\begin{array}{r}11 \\
2 \\
0 \\
1 \\
11 \\
8 \\
2 \\
2 \\
1 \\
1\end{array}$ & $\begin{array}{r}26 \\
5 \\
4 \\
2 \\
2 \\
32 \\
15 \\
9 \\
8 \\
1 \\
3\end{array}$ \\
\hline Total & 43 & 101 \\
\hline
\end{tabular}

Table 2. Planting stock production ${ }^{1}$ in Canada by province during 1989

\begin{tabular}{lccr}
\hline & \multicolumn{3}{c}{ (Millions of Seedlings) } \\
\cline { 2 - 4 } Province & Bareroot & Container & Total \\
\hline British Columbia & 30.0 & 290.0 & 320.0 \\
Alberta & 10.0 & 30.0 & 40.0 \\
Saskatchewan & 5.0 & 5.0 & 10.0 \\
Manitoba & 20.0 & 20.0 & 40.0 \\
Ontario & 75.0 & 85.0 & 160.0 \\
Quebec & 60.0 & 180.0 & 240.0 \\
New Brunswick & 7.0 & 43.0 & 50.0 \\
Nova Scotia & 9.0 & 18.0 & 27.0 \\
P. E. I. & 0.5 & 2.5 & 3.0 \\
Newfoundland & 5.5 & 8.5 & 14.0 \\
\hline Total & 222.0 & 682.0 & 904.0
\end{tabular}

${ }^{1}$ All these figures are approximate because at time of writing the official numbers for 1989 were not available. Official figures are generally released one year later

provincial research organizations and by those universities which had a forestry department. Except for insect and disease problems, the federal research centres did not become involved with stock production research until the mid 'sixties, with the onset of stock containerization.

Canada' research efforts in stock production have relied heavily upon the research conducted elsewhere in the world, in particular, the United States, Great Britain, Scandinavia and Finland, whose research programs have been far more advanced than ours. However, for the purpose of this overview only Canadian research has been cited.

The first Canadian forest tree nursery manual, dealing predominantly with soil management, appeared in 1961 (Armson and Carman 1961), with subsequent other manuals in 1969 (van den Driessche 1969a) and in 1974 (Armson and Sadreika 1974). These manuals synthesized nursery practices and research results from wherever applicable. The Canadian research content in these manuals, however, increased materially from 1961 to 1974 . The latest forest tree nursery manual (Duryea and Landis 1984), which is oriented towards the northwestern United States and Canada, also reflects Canada's increasing efforts in stock production research.

As in other countries, field performance after outplanting is an integral component of stock production research, and the boundary between stock production research and plantation establishment research is frequently vague. In this overview only research originating in the nursery will be examined and specific plantings to study plantation establishment are excluded. Further, the term field performance refers here to the collective name for both field survival and subsequent growth.

In Canada, the first research scientist working full-time in stock production was R. E. Mullin in Ontario, who started his research in 1953 and retired in 1980. Mullin worked on all aspects of stock production and was one of the first researchers to emphasize the importance of validifying results through the establishment of long-term field outplantings. The second full-time research scientist is $R$. van den Driessche in British Columbia, who started his research in 1959. These two scientists, together with a host of others, have made important contributions to the knowledge of stock production in Canada. 
The early research dealt solely with bareroot stock, but slowly an interest in containerized seedlings developed. In Canada, the development of producing tree seedlings in containers was initiated in the fifties by Walters $(1961,1974)$ at the University of British Columbia. The container developed by Walters, called the Walters' bullet, went through several modifications over the years, but never became an operationally viable container. The many apparent advantages of containerization, especially the potential for total mechanization of the entire artificial regeneration system, provided great incentives for development of containerization. However, Walters (1961) warned that developing suitable cultural techniques for raising large numbers of seedlings in containers would be difficult.

In Ontario, Mclean (1959) conducted a trial with tubed seedlings in a container now known as the Ontario tube (Ontario tubelings). Simultaneously, Williamson (1964) worked on the development of mechanizing all the components of the entire tubed seedling production system from seeding and growing to transporting and planting. Ontario adopted this system and began planting tubed seedlings operationally in 1965 with about 135000 tubelings. Production increased to about 17 million in 1966 and 19 million in 1967 and 1968, after which production decreased steadily because of poor survival and growth. No tubelings were planted after 1976. Kinghorn (1974) observed that the failure of the Ontario tubeling demonstrated how important it is to launch production-scale artificial regeneration programs only after large-scale field trials have delineated the biological and economic limitations of the system used. However, as Scarratt (1974) pointed out, much has been learned to make the planting of small young seedlings in small containers a viable regeneration option. Currently, a whole array of different containers are being used across Canada. Cayford (1972) has described the systems used in the 1950's and 1960's.

Walter's bullet system and the Ontario tubeling provided the impetus for the formation in 1967-1968 of a joint project between J. M. Kinghorn of the Canadian Forestry Service (CFS) and E. van Eerden and R. G. Matthews of the British Columbia Forestry Service (BCFS) to test out the bullet system. With Kinghorn as project co-ordinator, this project very quickly led to the development of the bullet-like extractable plug and the BC-CFS Styroblocks ${ }^{\circledR}$ in 1970 (Kinghorn 1970). The importance of air root-pruning also emerged from this project (Matthews 1971). A provisional manual for container seedling production was prepared by Matthews (1971) and subsequently Carlson (1979) prepared a set of guidelines for container seedling production.

Since the 'sixties, many meetings have been held in North America because of the rapid advent of the containerized seedling as a viable reforestation option. The first container planting workshop was held in 1968 in British Columbia to review the current programs and to discuss future research. The second workshop was held during September, 1971, at the Kananaskis Forest Experiment Station in Alberta with about 40 Canadian participants. The proceedings of this workshop were edited by Waldron (1972). An international meeting on containerized tree seedlings was held in September 1981 in Toronto, Ontario, with about 325 participants representing nine nations. The symposium co-chairman, K. H. Reese and J. B. Scarratt, pointed out that containerized planting stock production had increased from less than 20 million seedlings in 1972 to 135 million in 1981 , and was likely to exceed 200 million by 1983 (Scarratt et al.
1982). Thus, there was an urgent need for managers and researchers to get together and exchange information. At this meeting Kinghorn (1982) suggested that this be the last meeting devoted exclusively to container seedlings and that future meetings integrate discussion of container seedling production with bareroot production. However, Quebec has continued to sponsor some good container seedling workshops. The first one was in March, 1980, in Quebec City (Anon. 1980), the second one in November 1984 in SainteFoy (Anon. 1984), and the most recent one in November 1988 in Chicoutimi (Anon. 1988).

\section{Some Early Nursery Studies}

One of the first problems that Mullin wanted to solve was that of taking accurate inventory of the stock in bareroot nurseries. In testing sampling methods for nursery stock inventory he noted that the method used depended on species, stock-type, nursery bed size and percent accuracy required (Mullin et al. 1954, Mullin 1964b). Since culling and grading are routinely done at shipping time, Mullin (1959) undertook a culling and grading study from which he observed that culling only increased the survival of shipping stock by about $3.1 \%$ compared with shipping non-culled stock. There were also significant differences in culling practices between nurseries, suggesting the need for culling and grading standards (Mullin 1959). Ten years after outplanting he noted that initial stem diameter and height of planting stock were good indicators of field performance (Mullin and Svaton 1972).

In a study of planting depth and methods, Mullin found that the best method was that which gave the roots the best distribution throughout the soil and the best planting depth was slightly below (about $2 \mathrm{~cm}$ ) the nursery level (Mullin et al. 1954, Mullin 1964a). In testing various packaging methods and materials, Mullin (1954, 1958, 1980a) observed that the best materials were those which sealed in the moisture. A condensed literature review on the use of moisture retaining materials for packaging was done by Racey (1988); 18 of the 103 references cited were from Mullin.

\section{Planting Stock Size Studies}

The field performance of white pine (Pinus strobus L.), red pine $(P$. resinosa Ait.) and white spruce (Picea glauca (Moench) Voss) seedlings and transplants was compared extensively. In all cases, Mullin (1980b) found that transplants were superior to seedlings even 15 years after outplanting (Mullin and Howard 1973, Mullin and Christl 1982). These observations are in partial agreement with those of Dobbs (1976) who compared seedling, transplant and container stock of white spruce and lodgepole pine (Pinus contorta Dougl.). After three growing seasons Dobbs (1976) found that generally large seedlings or transplants outperformed small ones and those on scarified plots outperformed those on untreated plots. Vyse (1981) on the other hand concluded, after five years of observations on some 90 young spruce plantations, that size is over-emphasized in planting stock discussions. McMinn (1982) noted that stock size can and should be matched to site conditions, which means that seedling size should be matched to the intensity of vegetative competition.

Much work has been done in matching stock type to site, but much more remains to be done. The literature is full of conflicting observations, which is not surprising, because of the many variables involved. Many of these studies have only used survival and height as parameters for determining field 
performance. However, volume is a better parameter for measuring field performance and, therefore, a better indicator of site productivity than just survival and height (Glerum and Paterson 1989).

\section{Storage and Planting Season Extension Studies}

In a study of planting season extension with $2+0$ jack pine (Pinus banksiana Lamb.), $3+0$ black spruce (Picea mariana [Mill] B. S. P.) and $3+0$ white spruce,Sutton (1982) observed that even with imperfect cold storage, spring-lifted stock can be used successfully to extend the bareroot planting season in boreal Ontario until the end of July. Included in this study is a detailed literature review of other possible options available for extending the bareroot planting season. Of the 143 references cited 16 were by Mullin and 5 by K. M. McClain.

For successful overwinter storage of coniferous planting stock, a method had to be developed to determine the right time for lifting stock in the autumn. The degree hardening days method (DHD) was developed to assist the nursery manager to decide when to lift in the autumn for storage (Mullin and Parker 1976). DHD was calculated by accumulating daily differences below $10^{\circ} \mathrm{C}$ from soil temperatures of $15 \mathrm{~cm}$ depth. Subsequently, the electrical impedance technique (Glerum 1985) has been developed to determine when bareroot stock is ready for lifting in the autumn for overwinter frozen storage $\left(-3^{\circ} \mathrm{C}\right)$. Electrical impedance is now being used operationally in most Ontario bareroot nurseries as well as in one nursery in Manitoba.

Mullin conducted many overwinter storage trials with coniferous planting stock. He found that overwinter storage at $\mathrm{O}^{\circ} \mathrm{C}$ was totally unacceptable and properly sealed containers were superior to open containers for storage. Overwinter frozen storage $\left(-3^{\circ} \mathrm{C}\right)$ of the spruces was good, but that of the pines was variable. (Mullin and Bunting 1972; Mullin and Hutchinson 1978). This author believes that overwinter storage $\left(-3^{\circ} \mathrm{C}\right)$ is the best way to extend the planting season without any loss in field performance. The planting season can now be extended by frozen storage with container seedlings until mid-July (unpublished data).

\section{Seedling Nutrition Studies}

In the 'fifties, Armson (1960) initiated a study with white spruce to determine the pattern of nitrogen, phosphorus and potassium uptake, because no information on seasonal absorption of nutrients by tree species was available in Canada. He found that white spruce seedlings showed no evidence of a seasonal periodicity for absorption of nitrogen and potassium, but did show one for phosphorus. He also observed differences in nutrient uptake rates and suggested that fertilization might be more efficient if it coincided with periods of high nutrient uptake rates, as well as high relative growth rates. In another study, Armson (1968) observed that by manipulating soil fertility and seedbed density white spruce and red pine seedling stock with the desired characteristics could be produced. Similar results were obtained with white spruce at four levels of nitrogen, three levels of moisture supply and two seedbed densities, provided moisture supply was optimum (McClain and Armson 1976).

The soil pH in some of Ontario's nurseries was too high for growing conifers, especially red pine. To lower the $\mathrm{pH}$ Mullin (1964c, 1969) tested acidified water, peat and powdered sulphur. He found sulphur to be most effective for reducing $\mathrm{pH}$, which also resulted in better seedling size and subsequent field performance.
Nitrogen and phosphorus fertilization had a major positive effect on Douglas-fir seedlings growth (Pseudotsuga menziesii [Mirb.] Franco) and on subsequent field performance, but not on the frost hardiness (van den Driessche 1980). However, van den Driessche (1984), observed that the fertilization regime has to be well synchronized with the phenological development of the seedlings, because nitrogen can prolong growth if applied while the seedlings are still actively growing. In spite of all the nutrient studies that have been conducted, the correct timing and the proper frequency of fertilization is still not observed in many bareroot nurseries (van den Driessche 1984).

Fertilization of containerized seedlings is significantly different from that of bareroot seedlings. Nutrient reserves are considerably less in containers than in nursery seedbeds. Most of the nutrients required by a bareroot crop can be in the seedbed at time of sowing. With containers, nutrients have to be supplied throughout the growing season. Container crops are fertilized and irrigated simultaneously usually with a soluble (20-20-20) commercial fertilizer. A common practice is to deprive the plants of nitrogen for a few weeks towards the end of summer, while maintaining or increasing phosphorus and potassium. After bud set, the nitrogen supply is increased to promote bud development and food reserve accumulation (Brix and van den Driessche 1974). Timmer and Parton (1984) have demonstrated that tree seedlings have lower nutrient requirements than horticultural crops. They point out that it is important, therefore, to calibrate test procedures specifically for the containerized production of tree crops.

At present some promising approaches in container seedling nutrition are being studied, such as diagnosing the nutritional status of container seedlings by vector analysis (Timmer and Armstrong 1987a). In this analysis, directional differences in nutrient concentration, nutrient content and dry weight between plants of contrasting nutrient status are interpreted. This approach is a simultaneous comparison of growth and nutrients in an integrated and graphic format, thus facilitating diagnosis. Another approach is that of exponential fertilization, where the rate of fertilization is increased exponentially in concert with the exponential growth of the the tree seedling. In one such study (Timmer and Armstrong 1987b), the results indicated that superior seedlings can be produced at significantly lower fertilization levels than at conventional fertilization levels.

It is important to have standards in nutrition such as nutrient concentrations both in the soil and in plant tissues. The desirable working range for foliar nutrient concentrations of the five major elements for eight coniferous species and for several age-classes are given by Armson and Sadreika (1974). No such information, although much needed, is available for containerized tree seedlings.

Mycorrhizae generally are considered to be beneficial to tree seedling growth, because they enlarge root absorption area, which can translate into more efficient nutrient uptake. The symbiotic and synergistic relationship between mycorrhizae and trees are complex. Condensed reviews on this subject have been provided by Sutton (1969, 1980a). Containerized seedlings lend themselves well to mycorrhizal inoculations. Most of the mycorrhizae research in Canada has been done in Quebec, where container production rose from 29000 in 1980 to 90 million in 1986 (Margolis 1987). The beneficial effects of ectomycorrhizal inoculation is dependent on correctly matching the species 
of ectomycorrhizal fungus with each tree species and a fertilization schedule, and a growing media that allows for good mycorrhizal formation (Langlois and Fortin 1982 Gagnon et al. 1987).

\section{Seedling Water Relations}

The water flow continuum between soil-root-stem-air is disrupted as soon as bareroot stock is lifted. After outplanting the seedling's capacity for water uptake should be restored as soon as possible, which can only be done through the re-establishment of root contact with the surrounding soil by means of root growth. At time of lifting the plant moisture stress (PMS) of the seedlings should be low (Day 1984) and should remain low during the entire period from lifting to outplanting (i.e., during storage, shipping and planting). The most common instrument used for measuring PMS is the pressure chamber which can be used both in the laboratory and in the field (Day et al., 1985). Critical PMS, such as the wilting point, vary with the phenological development of the seedling, being high when the seedling is dormant and being considerably lower when the seedling is actively growing (Colombo 1987). The critical point (i.e., the wilting point) in black spruce was about 28 bars when the seedling was dormant, decreasing to about 14 bars when shoot elongation was active, and increasing to about 23 bars when bud development was completed (Colombo 1987).

\section{Frost Hardiness Studies}

In an experiment with 2-year old Douglas-fir, van den Driessche (1969b) found that the frost hardiness was clearly influenced by day length (i.e., photoperiod), night temperatures, and light, while the effects of moisture supply were confounded by photoperiod. At about the same time annual trends in frost hardiness and electrical impedance were established for the seven most common coniferous species in Ontario (Glerum 1973). In that study electrical impedance correlated well with changes in frost hardiness. This was substantiated by van den Driessche $(1973,1976)$, who found that stem electrical impedance correlated well with the frost hardiness changes of Douglas-fir, while the electrical conductivity methods correlated poorly with these changes. At that time it was hoped (Glerum 1980a) that electrical impedance could be used as a direct measure of frost hardiness (i.e., eliminating freezing tests) but that has not materialized (Glerum 1985).

Food reserves play an important role in the frost hardiness of trees. Hardy cells have sufficient quantities of food reserves in their cytoplasm. In a food reserve study with jack pine, white pine and white spruce seedlings, it was observed that food reserves do not play a direct role in wood formation of the secondary meristem (i.e., growth) but that wood formation is dependant on current photosynthate (Glerum and Balatinecz 1980; Glerum 1980b). Similar observations were made by van den Driessche (1987), who noted that the development of new root growth was dependant on current photosynthate. He also observed that the amount of new root growth was proportional to light intensity. In seedlings, the needles are as important as roots for the storage of food reserves (Glerum 1980b).

\section{Seedling Photoperiodicity Studies}

The effect of photoperiod on conifer seedlings has received considerable attention, particularly with the ever increasing interest in containerization. The results of this kind of research can be readily translated into operational practices. It is well established that spruces are sensitive to photoperiods. Vaartaja (1959) clearly documented the existence of photoperiodic ecotypes in many of our tree species, including white spruce, which is Canada's most widely distributed coniferous tree species (Stiell 1976).

In British Columbia altitude is an important factor to be considered when growing and planting tree seedlings. Through manipulation of photoperiod containerized spruces of both high and low altitude provenance can be grown at one production centre (Arnott 1974). By extending the photoperiod with supplemental light or by exposing the seedling crop to intermittent light, the limiting effects of photoperiod on spruces from northern latitudes (i.e., $50^{\circ}-58^{\circ}$ lat.) or high altitudes can be overridden. This means that all spruces can be grown in the southern coastal nurseries (i.e., at $49^{\circ}$ lat.) of British Columbia, where the long growing season will permit the production of healthy $1+0$ spruce seedlings (Arnott 1974). This type of photoperiodic manipulation can also be used for controlling seedling growth and thus enabling the production of uniform crops of long-day tree species (Arnott 1989). A long photoperiod stimulates growth and prevents bud set, while a short photoperiod stimulates bud initiation and stops leader elongation.

Temperatures also influence growth, with temperatures of $20^{\circ} \mathrm{C}$ to $25^{\circ} \mathrm{C}$ being optimum. Odlum and Colombo (1989) observed that under declining photoperiod, when day temperature was $26^{\circ} \mathrm{C}$, the optimum night temperature for bud initiation in black spruce seedlings was around $14^{\circ} \mathrm{C}$. Whether this is applicable to all spruces, remains to be determined.

The development of the Extended Greenhouse Culture (EGC) technique in the early 1980's by Colombo et al. (1984. 1989) made use of the knowledge gained on frost hardiness, photoperiodicity and food reserves. The EGC technique was developed for hardening spruce container seedlings in the greenhouse, before the crop was moved outside for overwintering. In this technique, frost hardiness and bud development are monitored during the autumn to determine when the seedlings can be safely moved outside for overwintering. The frost hardiness testing is done on seedling tops only, and does not provide root hardiness temperatures. Consequently, the guidelines laid down in the technique should be followed closely. The EGC technique is operational and widely used in many provinces. Since its development the technique has prevented severe overwinter damage to many millions of container seedlings.

\section{Seedling Root Studies}

Tree roots, including the root systems of nursery stock, have been studied extensively. Both root form and root growth have been of interest, and Sutton $(1969,1980 \mathrm{~b})$ has provided two good reviews on this subject. Most root systems of bareroot planting stock are deformed during planting (Sutton 1969). Most important is the degree of deformation severity and the effect that this has on the subsequent growth of the tree. The literature on this topic is full of contradictory observations (Sutton 1969). The protection of roots from deformation is one of the reasons for the ever increasing popularity of containerized seedlings. However, Van Eerden (1982) observed that after outplanting, root deformation in container-grown stock can also occur, but is usually less severe than in bareroot stock.

Regardless of whether we are growing bareroot or containerized seedlings, it is the capacity of the root system 
to grow after outplanting that is important. The success of an outplanted seedling depends on the speed with which the roots will grow after planting so that the roots establish contact with the surrounding soil for moisture, nutrients and stability. Promoting early root growth after planting should be a high priority because it increases the ability of seedlings to avoid drought (Brix 1979). The inherent problem in working with tree roots is their lack of visibility which makes developing methodology difficult.

One non-destructive method developed by Morrison and Armson (1968) involves measuring the root area of seedlings by means of a photoelectric cell in an instrument called a rhizometer. Since development of the rhizometer, the root area (usually referred to as root-area index) of bareroot stock is one of the morphological parameters measured at nearly all Ontario nurseries (Day et al. 1985). Another non-destructive method, called the volume displacement method (Burdett, 1979a), allows measuring the root volume of seedlings; a root is dipped into a vessel of water that is standing on a toploading balance; the resulting change in balance reading is an estimate of the root volume $\left(1.0 \mathrm{~g} \mathrm{H}_{2} \mathrm{O}=1.0 \mathrm{cc}\right)$. Racey (1985) noted that root volume estimates were as accurate and reproducible as root area index estimates. Every method has its limitations. Root volume does not determine root form, and abundance and length of white root tips can be considerably underestimated by the rhizometer (Morrison and Armson 1968; Racey 1985)

Root growth of nursery stock can be measured (Day et al. 1985): (1) by counting the number of white roots and white root tips, (2) by measuring the length of all the white roots, (3) by measuring the change in root area index from before to after the testing period, or (4) by measuring the change in root volume from before and after the test. The ability of seedlings to produce roots as soon as possible after planting is generally referred to as root growth capacity (RGC) and is considered to be an important physiological parameter of the quality of the seedling. Therefore, RGC is frequently measured at many nurseries, especially in British Columbia. Since counting and/or measuring white roots is time consuming, Burdett (1979b) developed a semi-quantitative index from 0 (i.e., no roots) to 5 (i.e., more than 30 new roots over $1 \mathrm{~cm}$ in length). Several other researchers have developed their own semi quantitative indices, depending on circumstances.

The interest in RGC is owing to its relationship with subsequent field performance. Since nursery cultural practices influence subsequent field performance, the latter is an integral part of most stock production projects. In this type of research, field performance is normally monitored until the plantation is well established. In many of these studies no relationship between $\mathrm{RGC}$ and subsequent field performance was found, but in others good positive relationships were found (Burdett 1987, Sutton 1980b, 1987). Therefore, it has been suggested that precise relationships between RGC and field performance need to be established (Burdett 1987 . Colombo and Asselstine 1989,Sutton 1987). A firm data base between RGC tests and field performance can only be achieved by rigorously standardized methodology, which involves precise documentation of growing medium, temperature, humidity, test duration, evaluation method and site factors. As Burdett (1987) points out, RGC does not predict survival but survival potential, and the type of relationship between the RGC test and field performance varies with site conditions. At present RGC tests probably provide the simplest method of evaluating the performance potential of planting stock.
In the 'fifties, planting check in white spruce caused considerable losses in growth (Mullin 1963, 1964d). Check exhibited itself when the terminal leaders of the white spruce trees did not elongate more than $2.5 \mathrm{~cm}$ per year, and it was observed to last for 10 to 15 years (Mullin 1964d). Damage to the root system at time of lifting, shipping and planting, seemed to be the major contributing factor to check. Interest in this type of check has decreased in recent years.

Root growth control in bareroot stock is important because the nurseryman wants to ship a well-balanced seedling for outplanting. Well-balanced means that the root system is fibrous and compact and that the top is sturdy. To control root growth the nurseryman has several cultural practices at his disposal, such as root pruning, undercutting and root wrenching. Sutton (1967) suggested that to avoid confusion in terminology, root pruning should refer to the chopping off of bare roots (i.e., after lifting), which is done mainly for convenience in handling and planting. Undercutting should refer to the severence of roots of seedlings still in the seedbed or transplant bed. Knowing when to undercut and/or wrench requires an understanding of both the soil and the species, and should be synchronized with the phenological development of the seedling. Racey and Racey (1988) have provided a good annotated bibliography of some 162 references on undercutting and root wrenching of tree seedlings.

Root growth control in container stock production is also important. By the time the container stock is ready for shipping and outplanting the roots should have formed a solidplug with the growing medium but should not be pot bound. Furthermore, the roots should not intertwine with neighbouring root systems. Copper sheeting and later copper paint were used to prevent the roots of Ontario tubelings from egressing, because copper inhibits root growth (Saul 1968). Shortly afterwards Scarratt (1972) suggested using perforated bottoms for the tubelings, so that the roots could be air pruned, which gave better results (i.e., no root deformations) than the copper. From the Ontario (Scarratt 1972) and British Columbia (Matthews 1971) experience, air root pruning became a firmly established practice. However, root deformation can still occur. To prevent it, Burdett (1978) raised lodgepole pine seedlings in styroblocks where the cavity walls were coated with a latex paint containing cupric carbonate. The copper inhibited the elongation of lateral roots in the cavities but when the seedlings were planted, the inhibited lateral roots resumed growth quickly. Consequently, the seedlings developed root systems quite similar to that of a naturally established seedling (Burdett 1978).

\section{Concluding Remarks}

As mentioned earlier, field performance after outplanting is an important component of many stock production research projects. Regrettably, this aspect of the project is often neglected because it is considered too expensive, and meaningful results take years to get. This should not deter stock production researchers because, in the long run, the results will justify the cost. However, not only should the researchers be committed to long-term monitoring of plantings, but so should the entire forestry community.

Forestry is still one of the main pillars of the Canadian economy, but can only remain so through adequate funding for research and for sound forest management. The federal government's constantly decreasing support of forest research and of many provincial forestry programs, is cause for grave concern. Moreover, many provinces provide 
inadequate support for their own forestry programs. There is still a fundamental lack of understanding for the integral role of forest management and forest research in maintaining the Canadian economy. Furthermore, sound forest management will also benefit the environment.

We need long-term commitments from all levels of government for sound forest management and research. A consistent source of funding is needed, which should be protected from the vagaries of budget making. The entire forestry community has the responsibility to promote good forest management based on biological knowledge, which can be obtained only through research, and should bring this continually to the attention of the general public.

Canada's contribution to stock production research since World War II, has been substantial, but there is no room for complacency. The future looks bright with the many young capable scientists that have now entered this area of research. However, they can only realize their potential if they get stable and adequate funding.

\section{Acknowledgements}

I am indebted to R. F. Sutton of Forestry Canada and P. A. Menes of this institute for reviewing the draft manuscript promptly at such short notice as well as for their many helpful suggestions. I am indebted also to T. J. Hodgson of Beaver Plastics Ltd., Edmonton, Alberta, for his help in the early stages of this manuscript. I wish to thank Donna-Marie McKay for all the typing and expediting this manuscript under a tight time schedule.

\section{References}

Anon. 1980. Atelier de travail sur la culture des semis en récipients. Quebec 18-20 mars. 1980. Centre de recherche forestière des Laurentides, Min. Energie Ressour. Qué., Ordre Ing. For. Qué.

Anon. 1984. Deuxième atelier de travail sur la culture des semis en récipients. Sainte-Foy, Qué. 29-30 novembre, 1984. Serv Can. des forêts, Min. Energie Ressour. Qué., Ordre Ing. For. Qué.

Anon. 1988. Troisième atelier Québécois sur la culture des plants forestiers en récipients. Chicoutimé Qué. 9-10 novembre 1988. Min. Energie Ressour. Qué., et Univ. Québec.

Armson, K. A. 1960. White spruce seedlings: the growth and seasonal absorption of nitrogen, phosphorus and potassium. Univ. Toronto For. Bull. No. 6. 37 p.

Armson, K. A. 1968. The effects of fertilization and seedbed density on the growth and nutrient content of white spruce and red pine seedlings. Fac. For. Univ. Toronto. Tech. Rep. No. 1014 p.

Armson, K. A. and R. D. Carman. 1961. A Manual for Forest Tree Nursery Soil Management. Ont. Dep. Lands and For. Toronto. Ontario $74 \mathrm{p}$.

Armson, K. A. and V. Sadreika. 1974. Forest Tree Nursery Soil Management and Related Practices. Ont. Min. Nat. Resourc. Toronto. 177p. (Metric edition is dated 1979 ISBN 0-7743-3224-7).

Arnott, J. T. 1974. Growth response of white and Engelmann spruce provenances to extended photoperiod using continuous and intermittent light. Can. J. For. Res. 4: 69-75.

Arnott, J. T. 1989. Regulation of white spruce, Engelmann spruce and mountain hemlock seedling growth by controlling photoperiod. Forestry Supplement 62: 157-168. ISSN 0015-752X.

Brix. H. 1979. Effects of plant water stress on photosynthesis and survival of four conifers. Can. J. For. Res. 9: 160-165.

Brix. H. and R. van den Driessche. 1974. Mineral nutrition of container grown tree seedlings. In: Proc. North Amer. Container. For. Tree Seedling. Symp. Aug. 26-29, 1974. Denver, Colo. (R. W. Tinus, W. I. Stein, and W. E. Balmer Eds.) Great Plains Agric. Council Publ. No. 68 pp. 77-84.)

Burdett, A. N. 1978. Control of root morphogenesis for improved mechanical stability in container-grown lodgepole pine. Can. J. For. Res. 8: 483-486.

Burdett, A. N. 1979a. A nondestructive method for measuring the volume of intact plant parts. Can. J. For. Res. 9: 120-122.
Burdett, A. N. 1979b. New methods for measuring root growth capacity: their value in assessing lodgepole pine stock quality Can. J. For. Res. 9: 63-67.

Burdett, A. N. 1987. Understanding root growth capacity: theoretical considerations in assessing planting stock quality by means of root growth tests. Can. J. For. Res. 17: 768-775.

Carlson, L. W. 1979. Guidelines for rearing containerized conife seedlings in the Prairie Provinces. Env. Can., Can. For. Serv. North. For. Res. Cent. Inf. Rep. Nor-X-214. $62 \mathrm{p}$

Cayford, J. H. 1972. Container planting systems in Canada. For Chron. 48: 235-239

Colombo, S. J. 1987. Changes in osmotic potential, cell elasticity, and turgor relationships of 2nd-year black spruce container seedlings. Can. J. For. Res. 17: 365-369.

Colombo, S. J. and M. F. Asselstine, 1989. Root hydraulic conductivity and root growth capacity of black spruce (Picea mariana) seedlings. Tree Physiol. 5; 73-81.

Colombo, S. J., C. Glerum and D. P. Webb, 1989. Winter hardening in first-year black spruce (Picea mariana) seedlings. Physiol. Plant. 76: 1-9.

Colombo, S. J., D. P. Webb and C. Glerum, 1984. Frost hardiness testing: An operational manual for use with Extended Greenhouse Culture. Ont. Min. Nat. Resourc. For. Res. Rep. No. 110. 14p. ISBN 0-7743-9479-X.

Day, R. J. 1984. Water management. In Forest Nursery manual Production of Bareroot Seedlings (M. L. Duryea and T. D. Landis eds.) pp. 93-105. Martinus Nijhoff/Dr. W. Junk Publ., The Hague. $385 p$

Day, R. J., W. R. Bunting, C. Glerum, E. M. Harvey, B. Polhill, K. H. Reese and A. Wynia. 1985. Evaluating the quality of bareroot forest nursery stock. (P. L. Aird ed.) Ont. Min. Nat. Resour. Toronto. ISBN 0-7729-0208-9.

Dobbs, R. C. 1976. Effect of initial mass of white spruce and lodgepole pine planting stock on field performance in British Columbia Interior. Can. For. Serv. Prac. For. Res. Cent. Inf. Rep. BC-X-149. $14 \mathrm{p}$.

Duryea, M. L. and T. D. Landis (Eds.). 1984. Forest Nursery Manual: Production of Bareroot Seedlings. Martinus Nijhoff/Dr. W. Junk Publ, The Hague. 385 p.

Gagnon, J., C. G. Langlois and J. A. Fortin. 1987. Growth of containerized jack pine seedlings inoculated with different ectomycorrhizal fungi under a controlled fertilization schedule. Can. J. For. Res. 17: 840-845.

Glerum, C. 1973. Annual trends in frost hardiness and electrical impedance for seven coniferous species. Can. J. Plant Sci. 53: $881-889$

Glerum, C. 1980a. Food sinks and food reserves of trees in temperate climates. N.Z. J. For. Sci 10: 176-185

Glerum, C. 1980b. Electrical impedance techniques in physiological studies. N. Z. J. For. Sci. 10: 196-207.

Glerum, C. 1985 . Frost hardiness of coniferous seedlings: principles and applications. In: Proc. Evaluating seedling quality: principles, procedures and predictive abilities of major tests. (M. L. Duryea Ed.). For. Res. Lab., Oregon State Univ. Corvallis, OR. pp. 107-123. ISBN 0-87437-000-0.

Glerum, C. and J. J. Balatinecz. 1980. Formation and distribution of food reserves during autumn and their subsequent utilization in jack pine. Can. J. Bot. 58: 40-54.

Glerum, C. and J. M. Paterson. 1989. Climatic influences on jack pine and black spruce during eight growing seasons since planting on a dry and a fresh site in northern Ontario. In: Climate applications in forest renewal and forest production. Proc. For. Climate ' 86 Nov. 17-20, 1986 Orillia. (D. C. Maclver, R. B. Street and A. N. Auclair Eds.) pp. 93-96. Atmospheric Env.Serv., Env. Canada. 307 p. ISBN 0-660-13096-3.

Kinghorn, J. M. 1970. The status of container planting in western Canada. For. Chron. 46: 466-469.

Kinghorn, J. M. 1974. Principles and concepts in container planting Ir. Proc. North Amer. Container. For. Tree Seedling Symp. Aug 26-29, 1974. Denver, Colo. (R. W. Tinus, W. I. Stein and W. E. Balmer Eds.) Great Plains Agric. Council Publ. No. 68. pp. 8-18.

Kinghorn, J. M. 1982. Summation: Containerization - boon or boondoggle? In: Proc. Can. Container. Tree Seedling Symp. Sept. 14-16, 1981, Toronto, Ontario. (J. B. Scarratt, C. Glerum and C. A. Plexman, Eds.). Can. For. Serv. COJFRC Symp. Proc. 0-P-10. pp. 425-427. ISBN 0-662-12250-X. 
Langlois, C. G. and J. A. Fortin. 1982. Mycorrhizal development of containerized tree seedlings. In: Proc. Can. Container. Tree Seedling Symp. Sept. 14-16, 1981, Toronto, Ontario. (J. B. Scarratt, C. Glerum and C. A. Plexman, eds.). Can. For. Serv. COJFRC Symp. Proc. 0-P-10. pp. 183-202. ISBN $0-662-12250-X$

Leavitt, C. 1913. Forest planting in Quebec. I. By the provincial government. In. Forest Protection in Canada, 1912. Commission Conserv. Can., Bryant Press, Toronto, Ont. pp. 134-137.

McClain, K. M. and K. A. Armson. 1976. Effect of water supply, nitrogen and seedbed density on white spruce seedling growth. Soil Sci. Soc. Amer. J. 40: 443-446.

Mclean, M. M. 1959. Experimental planting of tubed seedlings 1958. Ont. Dep. Lands and For., Res. Rep. 39. 13p

McMinn, R. G. 1982. Size of container-grown seedlings should be matched to site conditions. In: Proc. Can. Container. Tree Seedling Symp. Sept. 14-16, 1981, Toronto, Ontario. (J. B. Scarratt, C. Glerum and C. A. Plexman Eds.) Can. For. Serv. COJFRC Symp. Proc. 0-P-10. pp. 307-312. ISBN 0-662-12250-X.

Margolis, H. A. 1987. Seedling production and reforestation in Quebec. J. For. 85(8): 39-43.

Matthews, R. G. 1971. Container seedling production: A provisional manual. Can. For. Serv. Pac. For. Res. Cent. inf. Rep. BC-X-58. $48 p$.

Morrison, I. K. and K. A. Armson, 1968. The rhizometer - a device for measuring roots of tree seedlings. For. Chron. 44(5): 21-23.

Mullin, R. E. 1954. Nursery stock packaging experiment. Ont. Dep. Lands and Forests. Res. Rep. No. 27. 16p.

Mullin, R. E. 1958. An experiment with wrapping materials for bales of nursery stock. Ont. Dep. Lands and For. Res. Rep. No. 37. $31 p$

Mullin, R. E. 1959. An experiment on culling and grading of white spruce nursery stock. Part A. The percentage of cull. Ont. Dep. Lands and Forests. Res. Rep. No. 38. 62p.

Mullin, R. E. 1963. Planting check in spruce. For. Chron. 39: 252-259

Mullin, R. E. 1964a. Influence of planting depth on survival and growth of red pine. For. Chron. 40: 384-391.

Mullin, R. E. 1964b. Comparison of sampling methods for inventory of nursery stock. Tree Planters' Notes. No. 67: 3-8.

Mullin, R. E. 1964c. Acidification of a forest tree nursery soil. Soil Sci. Soc. Am. Proc. 28: 441-444

Mullin, R. E. 1964d. Reduction in growth of white spruce after outplanting. For. Chron. 40: 488-502.

Mullin, R. E. 1969. Soil acidification in a forest nursery. Commonwealth For. Rev. 48: 284-285

Mullin, R. E. 1980a. Is moss necessary in all nursery stock packaging? For. Chron. 56: 109-111

Mullin, R. E. 1980 b. Comparison of seedlings and transplant performance following 15 years growth. For. Chron. 56: 231-232.

Mullin, R. E. and W. R. Bunting. 1972. Refrigerated overwinter storage of nursery stock. J. For. 70: 354-358.

Mullin, R. E. and C. Christl. 1982. Morphological grading of white pine nursery stock. For. Chron. 58: 40-43.

Mullin, R. E. and C. P. Howard. 1973. Transplants do better than seedlings, and... For. Chron. 49: 213-218.

Mullin, R. E. and R. E. Hutchison. 1978. Fall lifting dates, overwinter storage and white pine seedling performance. For. Chron. 54: 261-264.

Mulling, R. E., L.M. Morrison and T.T. Schweitzer. 1955. Inventory of nursery stock. Ont. Dep. Lands and For. Res. Rep. No. 33. 64p.

Mullin, R. E. and J. D. Parker. 1976. Provisional guidelines for fall lifting for frozen overwinter storage of nursery stock. For. Chron. 52: 22-25

Mullin, R. E., T. T. Schweitzer and L. M. Morrison. 1954. Planting depths and methods experiments. Ont. Dep. Lands and For. Res. Rep. No. 26. 26p.

Mullin, R. E. and J. Svaton. 1972. A grading study with white spruce nursery stock. Commonwealth For. Rev. 51: 62-69.

Odlum, K. D. and S. J. Colombo, 1989. The influence of night temperature under declining photoperiod on bud initiation in black spruce seedlings. Can. J. For. Res. 19: 274-275

Racey, G. D. 1985. A comparison of planting stock characterization with root-area index volume and dry weight. For. Chron. 61: $64-70$
Racey, G. D. 1988. Moisture retaining materials for tree seedling packaging: a literature review. Ont. Min. Nat. Resour., For. Res. Rep. No. 120. 16 p. ISBN 0-7729-3606-4.

Racey, J. E. and G. D. Racey. 1988. Undercutting and Root Wrenching of Tree Seedlings: An Annotated Bibliography. Ont. Min. Nat. Resour., For. Res. Rep. No. 121. 79 p. ISBN 0-7729-3607-2.

Reed, F. L.C. and Associates Ltd. 1978. Forest management in Canada. Vol. 1. A Study to Improve the Basis for Policy Formulation, Planning and Practice in Intensive Forest Management. Env. Can., Can. For. Serv. Info. Report FMR$X-102.155 p$

Saul, G. H. 1968. Copper safely controls roots of tubed seedlings USDA For. Serv., Tree Planters' Notes. 19; 7-9.

Scarratt, J. B. 1972. Air-space controls root extension from openended containers during seedling production. For. Chron. 48 242-245.

Scarratt, J. B. 1974. Performance of tubed seedlings in Ontario. In Proc. North Amer. Container. For. Tree Seedling Symp. Aug. 26-29, 1974, Denver, Colo. (R. W. Tinus, W. I. Stein and W. E. Balmer Eds.) Great Plains Agric. Council Publ. No. 68. pp. 310-320

Scarratt, J. B., C. Glerum and C. A. Plexman. (Eds.) 1982. Proc Canadian Containerized Tree Seedling Symposium, Toronto Ontario, Sept. 14-16, 1981. Env. Can., Can. For. Serv. COJFRC Symp. Proc. 0-P-10. 460 p. ISBN 0-662-12250-X.

Sisam, J. W. B. 1982. Forestry and forestry education in a developing country: a Canadian dilemma. Fac. For., Univ. Tor., Univ Toronto Press. 167 p. ISBN 0-7727-4600-1

Smyth, J. H. and A. J. Brownwright. 1986. Forest tree production centres in Canada. Can. For. Serv., Great Lakes For. Cent Inf. Rep. 0-X-378 53 p. ISBN 0-662-15071-6.

Stiell, W. M. 1976. White spruce: artificial regeneration in Canada Env. Can., Can. For. Serv. Ottawa Info. Rep. FMR-X-85. 275 p.

Sutton, R. F. 1967. Influence of root pruning on height increment and root development of outplanted spruce. Can. J. Bot. 45 $1671-1682$

Sutton, R. F. 1969. Form and Development of Conifer Root Systems. Commonwealth For. Bur., Tech. Comm. No. 7. $131 \mathrm{p}$

Sutton, R.F. 1980a. Root system morphogenesis. N.Z. J. For. Sci. 10: $264-292$

Sutton, R. F. 1980b. Planting stock quality, root growth capacity, and field performance of three boreal conifers. N.Z. J. For. Sci. 10: $54-71$

Sutton, R. F. 1982. Plantation establishment in the boreal forest: planting season extension. Env. Can., Can. For. Serv., Great Lakes For. Cent. Inf. Rep. 0-X-344, 129 p. ISBN 0-662-12298-4.

Sutton, R. F. 1987. Root growth capacity and field performance of jack pine and black spruce in boreal stand establishment in Ontario. Can. J. For. Res. 17: 794-804

Timmer, V. R. and G. Armstrong. 1987a. Diagnosing nutritional status of containerized tree seedlings: comparative plant analyses. Soil Sci. Soc. Am. J. 51: 1082-1086.

Timmer, V.R. and G. Armstrong. 1987b. Gro'vth and nutrition of containerized Pinus resinosa at exponentially increasing nutrient additions. Can. J. For. Res. 17: 644-647

Timmer, V.R. and W.J. Parton. 1984. Optimum nutrient levels in a container growing medium determined by a saturated aqueous extract. Commun. Soil Sci. Plant Anal. 15: 607-618.

Vaartaja, 0.1959. Evidence of photoperiodic ecotypes in trees. Ecol Monogr. 29: 91-111

van den Driessche, R. 1969a. Forest Nursery Handbook. B. C. For Serv. Victoria. Res. Note $48.44 p$.

van den Driessche, R. 1969b. Influence of moisture supply, temperature and light on frost hardiness changes in Douglas-fir seedlings. Can. J. Bot. 47: 1765-1772

van den Driessche, R. 1973. Prediction of frost hardiness in Douglasfir seedlings by measuring electrical impedance in stems a different frequencies. Can. J. For. Res. 3: 256-264.

van den Driessche, R. 1976. Prediction of cold hardiness in Douglas-fir seedlings by index of injury and conductivity methods. Can. J. For. Res. 6: 511-515

van den Driessche, R. 1980. Effects of nitrogen and phosphorus fertilization on Douglas-fir nursery growth and survival after outplanting. Can. J. For. Res. 10: 65-70. 
van denDriessche, R. 1984. Soil fertility in forest nurseries. In: Forest Nursery Manual: production of Bareroot seedlings. (M. L. Duryea and T. D. Landis Eds.) p. 63-74. Martinus Nijhoff/Dr. W. Junk Publ; The Hague. $385 \mathrm{p}$.

van den Driessche, R. 1987. Importance of current photosynthate to new root growth in planted conifer seedlings. Can. J. For. Res. 17: 776-782.

van Eerden, E. 1982. Root form of planted trees. In. Proc. Can. Container. Tree Seedling Symp. Sept. 14-16, 1981. Toronto, Ontario. (J. B. Scarratt, C. Glerum and C. A. Plexman, Eds.) Can. For. Serv. COJFRC Symp. Proc. 0-P-10. pp. 401-405. ISBN 0-662-12250-X.

Vyse, A. 1981. Growth of young spruce plantations in interior British Columbia. For. Chron. 57: 174-180.
Waldron, R. M. (Ed.) 1972. Proceedings of a workshop on container planting in Canada. Env. Can., Can. For. Serv. Inf. Rep. DPC-X-2. $168 \mathrm{p}$.

Walters, J. 1961. The planting gun and bullet: a new tree-planting technique. For. Chron. 37: 94-95, p. 107.

Walters, J. 1974. Engineering for injection planting. In: Proc. North Amer. Container. For. Tree Seedling Symp. Aug. 26-29, 1974, Denver, Colo. (R. W. Tinus, W. I. Stein and W. E. Balmer Eds.) Great Plains Agric. Council Publ. No. 68. pp. 241-243.

Williamson, V.H.H. 1964. Preparation and planting of tubed seedlings. Ont. Dep. Lands and Forests, Res. Rep. 52, 9 p.

Zavitz, E. J. 1947. Reforestation in Ontario. Can. Geogr. J. 34(4): $156-180$.

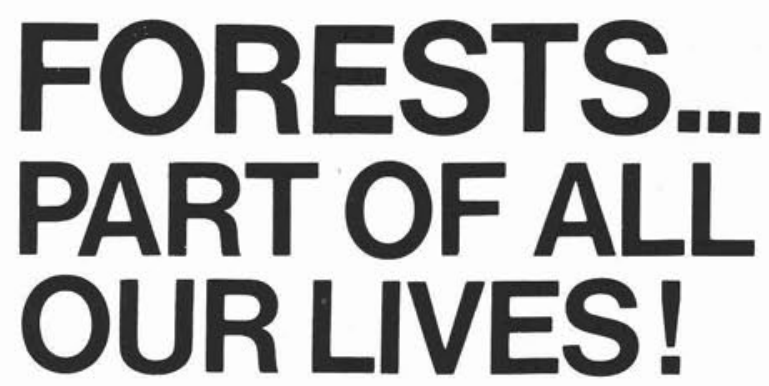

\section{Canada's Timber Resources A National Conference}

\section{June 3-6, 1990, Conference Centre, Victoria, B.C.}

A broad range of speakers from across Canada will address the current status of Canada's forests, their rate of change and the long run timber supply. Technical sessions will include presentations of case studies and papers describing innovative approaches to growth and yield estimation, forest regulation, integrated forest resource management and timber supply forecasting.

For information on registration, conference program, poster session, accommodation and travel, contact:

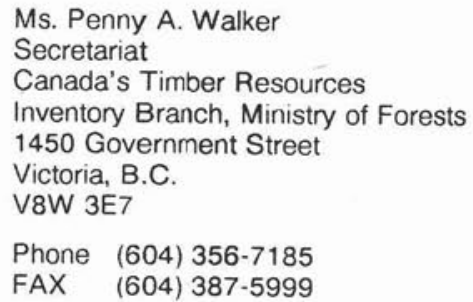

Sponsored by: Forestry Canada and B.C. Ministry of Forests

$\begin{array}{ll}\text { Forestry } & \text { Forêts } \\ \text { Canada } & \text { Canada }\end{array}$

